\title{
多層カーボンナノチューブへのホウ素ドープ
}

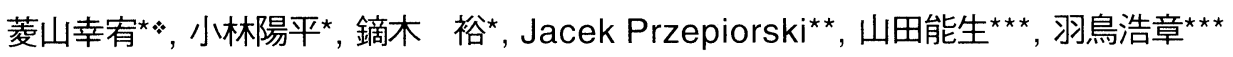

(平成14年7月12日受理, 平成14年10月29日採択)

\section{Boron Doping to Multiwall Carbon Nanotube}

\author{
Yoshihiro Hishiyama**, Yohei Kobayashi*, Yutaka Kaburagi*, Jacek Przepiorski**, \\ Yoshio Yamada*** and Hiroaki Hatori***
}

\begin{abstract}
Boron doping to carbon nanotube was carried out on pressed samples of multiwall carbon nanotube (MWCNT) prepared by a CVD method. As-prepared sample was pressed as disks of $20 \mathrm{~mm}$ in diameter with an apparent density of $0.72 \mathrm{~g} \cdot \mathrm{cm}{ }^{3}$. The disks were heat-treated at $3000^{\circ} \mathrm{C}$ to remove iron impurity. From the heat-treated disks, samples with sizes about $1.5 \times 1.5 \times 6 \mathrm{~mm}^{3}$ were cut. Boron doping was carried out by heating the sample to $2300^{\circ} \mathrm{C}$ in a crucible made of a commercially available artificial graphite contained $10 \mathrm{wt} \%$ born. We employed $1 \mathrm{hr}$ heat treatment as a unit of doping treatment, and carried out doing of 1 to 3 times for the samples. Boron concentrations of the boron-doped samples were determined by an EPMA technique. Structural characterization of the doped samples was made with Xray diffraction and Raman spectroscopy measurements and SEM observation. The characterization revealed that almost of born doped samples were consisted of MWCNT's contained boron, small thin boron-contained crystallites with graphite structure and $\mathrm{B}_{4} \mathrm{C}$ small crystals. Effect of boron doping was examined by the measurements of electrical resistivity at liquid nitrogen and room temperatures and magnetic susceptibility at 5 and $300 \mathrm{~K}$ as a function of boron concentration for the boron-doped samples.
\end{abstract}

KEYWORDS : Carbon nanotube, Raman spectroscopy, X-ray diffraction, Electrical resistivity, Magnetic susceptibility

\section{1. はじめに}

カーボンナノチューブの発見以来", 多数の単層ナノチュー ブや多層ナノチューブ, またそれぞれの形態や凝集状態など が異なった種々のチューブが見出され，その構造, 物性など基 礎的特性に関する研究が盛んに行われている。特にカーボン ナノチューブは, 例えば単層カーボンナノチューブの場合は そのカイラリティーによって半導性から導電性への変化が可 能であることが理論的に解明され21, 興味がもたれている。し かし, 現在のところナノチューブの構造から電子物性を制御 することは実験的には大変困難である。

これに対してグラファイトなどでは, 構成炭素の一部をホ ウ素原子に置換することは可能で, 著者らはホウ素置換グラ ファイトの電子物性などの変化に関する研究を行ってきた3!。 筆者らの研究では, 芳香族ポリイミドKaptonから調製した高
配向性高品位グラファイトフィルムを市販の $10 \mathrm{wt} \%$ のホウ素 を含有する人造グラファイト板の間に挟み, 2350 ～ $2500^{\circ} \mathrm{C} の$ 温度に加熱処理することによってホウ素ドープを行った。そ の結果, ホウ素ドープすることによってホウ素原子がグラフ アイト格子の炭素原子と置換し, 格子定数 $a_{0}$ が増加し, $c_{0}$ が減 少し, 0.4at\%程度のホウ素ドープによってフェルミ準位が下 部爪バンドの頂上から深く押し下げられ, キャリヤー構成が正 孔単独になることがわかった。ホウ素ドープ試料はX線的に は無限大寸法の結晶粒からなる高配向性の多結晶体で, ホウ 素ドープによる原グラファイトフィルムの高配向性の乱れは 高ホウ素濃度試料に対して見られる程度であった。しかし， このホウ素ドープによる結晶性の乱れはラマン散乱から見る と非常に大きく, $0.4 \mathrm{at} \%$ 程度のホウ素ドープは $\mathrm{G}$ バンドに対 する相対強度の比較的大きいDバンドを生ぜしめる。Dバン ドの相対強度は2.2at％のホウ素を含有する高濃度試料では極

* Corresponding Author, E-mail: yhishiya@eng.musashi-tech.ac.jp

* 武蔵工業大学工学部エネルギー基礎工学科：テ158-8557 東京都世田谷区玉堤1-28-1

* Department of Energy Science and Engineering, Faculty of Engineering, Musashi Institute of Technology : 1-28-1 Tamazutsumi, Setagaya-ku, Tokyo 158-8557, Japan

** Technical University of Szczecin, ul. Pulaskiego 10, 70-322 Szczecin, Poland

*** 产業技術総合研究所エネルギー利用研究部門：テ305-8569 茨城県つくば市小野川16-1

*** Institute for Energy Utilization, National Institute of Advanced Industrial Science and Technology : 16-1 Onogawa, Tsukuba-shi, Ibaraki 305-8569, Japan 
めて大きくなる。この乱れに関連した現解として電子物性に 拐いては弱局在効果が見られた。この弱局在効果は低温で観 測される量于効果で, 磁場の平方根に比例する偩磁気抵抗と 絶対温度の㤃方根に比例する電気抵抗㻭がその特性である。

この研究で用いたホウ素ドープの手法は1種の搪散法で, 多 少の收良を加え机ば多層カーボンナノチューブ (Multi-wall carbon nanotube, MWCNTと略記する) に適用可能で, MWCNT に执いても东学置換が期待でき, 電子物性の応用面に执け る叮能性が開けてくると考えられる。すでにこれまでにナノ チューブへのホウ素, あるいはホウ素/窒素をドープする研 究はいくつか行われてきている4-8〉。これらの研究では, 電槁

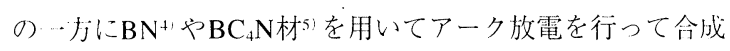
する方法, アセチレンノジボラン混合ガスの熱分解で合成す るカ法("), ナノチューブを高温で $\mathrm{B}_{2} \mathrm{O}_{3}$ の蒸気と接触させてド 一プさせる方法7188などが行われているが，ドープ量が非常に 少なかったり，ドープしたホウ素の不均一性や制御の困難性 に执いて問題点がある。そこで著者らは, 上記グラファイト へのホウ素置換法をMWCNTに適用してホウ素ドープを試 み,ドーピングによる効果を構造と物性の面から考察した。

\section{2. 実 験}

\section{1 試料}

本䒠験で用いたMWCNTは，酸化鉄を触媒としてベンゼン の気相熱分解によって合成したものを用いた。すなわち、ア ルミナに硝酸鉄を分散させ，これを焼成して調製した酸化鉄 担持アルミナ粒子をセラミックボートに入れ, 石英反応管に 設置して $9000^{\circ} \mathrm{C}$ で水素: ベンゼン $=9: 1$ 混合ガスを流通させ ながら触媒上でナノチューブを析出させた。得られたナノチ ユーブを超音波によってエタノールに分散させて採取したも のである。

透過電子顕微鏡の観察から,このナノチューブ（MWCNT） はストレートな同軸炭素円筒網面ではなく, 比較的一様な部 分もあるが, MWCNTが絡み合った集合体である。比較的一 様な部分の直径は 9 13nm, 内径は〜2 $6 \mathrm{~nm}$, 隣接炭素円 筒面間の間隔は $0.34 \mathrm{~nm}$ の程度であり, 同軸円筒を形成する 層の数は10１4であることがわかった。MWCNTの先端には 殻があり，钤の中には長球状の金属微粒子が納まっている。 蛍光X線分析の結果, 金属微粒子は鉄微粒子と同定された。

本報に抢けるMWCNTの構造の検討はX線回折とRaman分 光と走查電子顕微鏡観察とによって行い, 物性の検討は電気 抵抗率, 磁気抵抗および磁化率の測定によって行うこととし た。これらの物性測定のためには試料は成型体でなければな らない。得られたMWCNT (as-prepared試料) は, 粉末状では あるが, 加圧成型が可能である。よって, MWCNTは直径 $20 \mathrm{~mm} \phi$, 厚さ $2 \mathrm{~mm}$, かさ密度 $0.72 \mathrm{~g} \cdot \mathrm{cm}^{-3}$ の円板に加圧成形した。 加圧成形体には鉄微粒子が含まれているから, 磁化率測定 のためにはこれを除去する必要がある。鉄微粒子は, 加圧成
Table 1 Results on fluorescence X-ray analysis for MWCNT sample pressed at room temperature and then heattreated at $900^{\circ} \mathrm{C}$ and its $3000^{\circ} \mathrm{C}$-treated samples.

\begin{tabular}{|c|c|c|c|c|c|}
\hline Sample & $\begin{array}{c}\mathrm{C} \\
(\mathrm{wt} \%)\end{array}$ & $\begin{array}{c}\mathrm{Al} \\
(\mathrm{wt} \%)\end{array}$ & $\begin{array}{c}\mathrm{S} \\
(\mathrm{wt} \%)\end{array}$ & $\begin{array}{c}\mathrm{Fe} \\
(\mathrm{wt} \%)\end{array}$ & $\begin{array}{c}\mathrm{Mo} \\
(\mathrm{wt} \%)\end{array}$ \\
\hline $900^{\circ} \mathrm{C}$-treated & 97.17 & 2.15 & 0.04 & 0.62 & 0.02 \\
\hline $\mathrm{A}$ & 100.00 & 0.00 & 0.00 & 0.00 & trace \\
\hline $\mathrm{B}$ & 100.00 & 0.00 & 0.00 & 0.00 & 0.00 \\
\hline $\mathrm{C}$ & 100.00 & 0.00 & 0.00 & 0.00 & 0.00 \\
\hline
\end{tabular}

形体を $3000^{\circ} \mathrm{C} に$ 熱す机ば除去することができる。そこで， 加压成形体は $3000^{\circ} \mathrm{C}$ で熱处理し, 熱処理体をホウ素ドープ 月試料とした。加閎成形体を直接 $3000^{\circ} \mathrm{C}$ に加熱すると, 破填 する恐机があるので, $900^{\circ} \mathrm{C}$ に予備加熱しておき, さらに

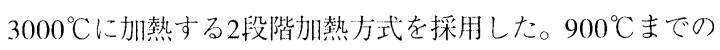
加熱処理は, 郝線イメージ炉を用い, 試料を等素気流中で $900^{\circ} \mathrm{C}$ まで $40^{\circ} \mathrm{C} / \mathrm{hr}$ の列温速度で昇温し, $900^{\circ} \mathrm{C}$ に時間保持し

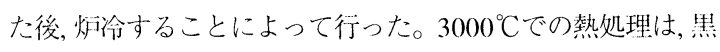
鉙抵抗炉を用いて行った。熱処理用試料は, $900^{\circ} \mathrm{C}$ 处理試料を ダイヤモンド回転刃を用いて2つに切断した切断片である。 切断片試料は2枚の高純度黑鉛板の間に挟み, 周囲を炭素撚系 で縛り,これを炉中に収納し、アルゴン気流中 $3000^{\circ} \mathrm{C} て ゙$ 熱处理

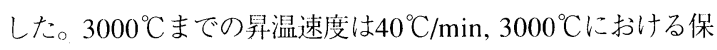
持時間は5, 22, 30分の3通りとした。熱処理試料は熱処理時間 の順にA, B, Cと記す。

$900^{\circ} \mathrm{C}$ 処理試料および試料 $\mathrm{A}, \mathrm{B}, \mathrm{C}$ 対しては,鉄ならびにそ のほかの不純物の含有量を調べるために蛍光X線分析を行っ た。分析結果をTable 1 に示す。 $900^{\circ} \mathrm{C}$ 処理試料の結果はその 1 例であるが, $900^{\circ} \mathrm{C}$ 処理試料には, この程度の不純物が含有さ れていると判断する。 $3000^{\circ} \mathrm{C}$ 処理試料Aには, Moが不純物と して痕跡的 (0.01 wt\%以下) に検出されたものの, 試料 $\mathrm{B}, \mathrm{C} に$ は蛍光X線分析の精度の範囲では他元素は検出できなかった。

\section{2 ホウ素ドープ}

熱処理試料A，B，Cのホウ素ドープは，拡散法によって行っ た。すなわち,ホウ素含有黑鉛片に熱処理試料を接触させた 状態で, 高温処理することにより熱処理試料にホウ素を拡散 させる方法によった。高温処理には, ホウ素ドープ専用の黑 鉛抵抗炉を用いた。

試料A，B，Cそれぞれから，寸法 $1.5 \times 1.5 \times 6 \mathrm{~mm}^{3}$ の試片を切 り出し, 試料自体の物性測定用試片およびホウ素ドープ用試 片とした。ホウ素拡散源は市販の10重量\%ホウ素含有の黑鉛 ブロック(東洋炭素(侏)GB110) から作製した坩堝で,この中に ホウ素ドープ用試片を収納し，坩堝をアルゴン気流中で $2300^{\circ} \mathrm{C}$ に1時間保持することによって1回のドープ处理とし， 処理の回数を1〜3回としてホウ素ドープ处理を行った。処理 回数の増加は処理時間の増加に対応するが, 連続した長時間 処理を避けたのは, 1 回の熱处理における坩堝から黒鉛発熱体 へのホウ素拡散が同程度に行われることを想定したからであ 
Table 2 Treatment time at $3000^{\circ} \mathrm{C}$ before boron doping HTt and number of boron doping sequences $n_{B}$ and boron concentration determined by electron probe microanalysis (at \% boron) for boron-doped samples. Original samples for boron doping are MWCNT samples pressed at room temperature and then heattreated at $3000^{\circ} \mathrm{C} .1$ boron doping sequence is heat treatment at $2300^{\circ} \mathrm{C}$ for $1 \mathrm{hr}$.

\begin{tabular}{|c|c|c|c|}
\hline Sample & $\mathrm{HTt}(\mathrm{min})$ & $n_{B}$ & at \% boron \\
\hline A-B2 & 5 & 2 & 0.87 \\
\hline B-B1 & 22 & 1 & 0.73 \\
\hline B-B2 & 22 & 2 & 0.90 \\
\hline C-B1 & 30 & 1 & 0.72 \\
\hline C-B2 & 30 & 2 & 0.61 \\
\hline C-B3 & 30 & 3 & 1.06 \\
\hline
\end{tabular}

る。したがって, 処理回数の高い試料においてはホウ素濃度 がより高くなることが期待できる。

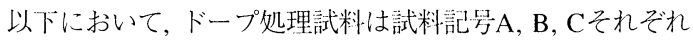
の後に-Bをつけ, さらにドープ回数をつけることによって表 わす。Table 2にはドープ処理試料のドープ処理前の $3000^{\circ} \mathrm{C}$ 処理における処理時間 $\mathrm{HTt}$, ドープ処理回数 $n_{B}$ を示した。

各ホウ素ドープ試料のホウ素濃度 $\left(x_{B}:\right.$ at \% boron) をEPMA 装置JXA8200を用いて求めた。結果をTable 2 に示す。試料 $\mathrm{C}-\mathrm{B} 1$ とC-B2の $x_{B}$ の值と $n_{B}$ との間に逆転が見られるが, $x_{B}$ は $n_{B}$ とともに增加しており, 試料 $\mathrm{A}, \mathrm{B}, \mathrm{C} に は 0.61 \sim 1.06 \mathrm{at} \%$ 範囲 でホウ素ドープすることができた。

\section{3 測定}

\subsection{1 ラマンスペクトル}

ラマンスペクトルは炭素材料の構造の乱れを敏感に反映す るから, ホウ素ドープによって導入される構造の乱れにも敏 感であると考えられる。そこで1次および2次ラマンスペクト ルをas-prepared試料, $900^{\circ} \mathrm{C}$ 処理試料およびホウ素ドープ試料 に対し, 空気中, 室温で測定した。試料内部の構造知見が得ら れるよう, 試料端部を破断し, 破断面に対してラマンスペクト ルを測定した。用いた装置はJOBIN YBON RAMANOR T6400で, 入射レーザー光の波長は514.5nmで, レーザー光のビ 一ム径は $10 \mu \mathrm{m}$ とした。本装置では試料のレーザー光照射面 の面積 $1 \mu \mathrm{m}^{2}$ をディスプレー上に $1 \mathrm{~cm}^{2}$ 程度の拡大像として表 示することができるので，この程度の倍率で照射面には MWCNTのみが含まれるようにした。散乱光は照射面から数 十nmより深いところからは検出し得ないので, 本実験から得 られる知見はほぼMWCNTからのものとすることができる。 ただし, as-prepared試料および $900^{\circ} \mathrm{C}$ 処理試料はレーザー光照 射によってダメージを受けるので, レーザー光のパワーを通 常測定におけるよりも約 $1 / 100$ に落として測定した。測定の 振動数域は, as-prepared試料および $900{ }^{\circ} \mathrm{C}$ 処理試料の場合は $800 \sim 3500 \mathrm{~cm}^{-1}, 3000^{\circ} \mathrm{C}$ 処理試料およびホウ素ドープ試料の 場合は1150〜3500 $\mathrm{cm}^{-1 と し た 。 ~}$

\subsection{2 電気抵抗率, 磁気抵抗}

電気抵抗率 $\rho$ および磁気抵抗 $\Delta \rho / \rho_{0}$ は淔流4端子法によって 室温および液体窒素温度において測定した。導線には $0.05 \mathrm{~mm} \phi$ の金線を用い, 金線と試料との接続は金ぺイントに よった。 $\rho$ はすべての試料に対して空温および液体窒素温度 において測定した。 $\Delta \rho / \rho_{0}$ は1Tまでの磁場を加えて測定した が, 室温および液体窒素温度においては検出できなかった。

\subsection{3 磁化率}

磁化摔はスクイッド磁束計MPMS 5Sを用い, 試料B, B-B 1

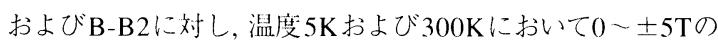
磁場領域における磁化の測定によって検討した。

\subsubsection{X線回折}

X線回折測定はas-prepared試料, $900{ }^{\circ} \mathrm{C}$ 処理試料の粉末試料 に対しCu K $\alpha$ 線を用いて行った。使用装置はX線ディフラク トメーターRigaku RINT 2000である。3000 C 処理試料A，B， C およびそれらのホウ素ドープ処理試料すべてに対しては, 物性測定後これらを粉末にして測定を行った。外部標準とし て高純度Si粉末を用いた。

\subsection{5 走査電子顕微鏡観察}

$900^{\circ} \mathrm{C}$ 処理試料, $3000^{\circ} \mathrm{C}$ 処理試料 $\mathrm{A}, \mathrm{B}, \mathrm{C}$ およびそれらの木 ウ素処理試料の破断面を電界放计走查顕微鏡 (FESEM) で観 察した。また, as-prepared試料の粉末試料についても観察し た。用いたFESEMはHitachi S-4100で, 観察のための前処理 は行わなかった。また, 1次電子ビームの加速電圧は $4.0 \mathrm{kV}$ と して観察を行った。熱処理後およびホウ素ドープ後の MWCNTの形態変化を検討するために, as-prepared試料, $3000^{\circ} \mathrm{C}$ 処理試料 $\mathrm{B}$ ，ホウ素ドープ処理試料 $\mathrm{A}-\mathrm{B} 2$ および $\mathrm{B}-\mathrm{B} 1$ を 高分解能セミインレンズ型FESEM, JEOL JSM 6700Fによっ て観察した。その際, 試料には親水処理を施し, 研磨したガラ ス状炭素試料台上に分散させた後観察した。観察のための 1次電子ビームの加速電压は $5.0 \mathrm{kV}$ とした。

\section{3. 結果と考察}

\section{$3.1 \mathrm{X}$ 線回折}

\section{1 .1 末ドープ試料}

as-prepared試料, $900^{\circ} \mathrm{C}$ 処理試料，および $3000^{\circ} \mathrm{C}$ 処理試料 $\mathrm{A}$, B, CのX線回折パターンをFig.1に示す。

Fig.1 (a) に示すように, as-prepared試料および $900^{\circ} \mathrm{C}$ 処理試 料の回折パターンはMWCNTとナノボールからなる系の回折 パターンに類似している9!。両試料の回折線に原子散乱因子 およびローレンツ偏光因子に対する補正を施し, 002線から平 均面間隔 $d_{002}$ および平均結晶子厚み $L_{c}$ を求めた結果をTable 3 に表示する。両試料に対して得られたこれらの值はそれぞれ まったく同等であった。得られた $d_{002}$ の值はMWCNTの同心 円筒網面間の間隔に対応し, $L_{c}$ の值は入射X線に対するコヒー レントな円筒網面間の平均距離に対応する。なお, 11 回折線 から求めた両試料の格子定数 $a_{0}$ と格子寸法 $L_{a}$ の值はそれぞれ, 

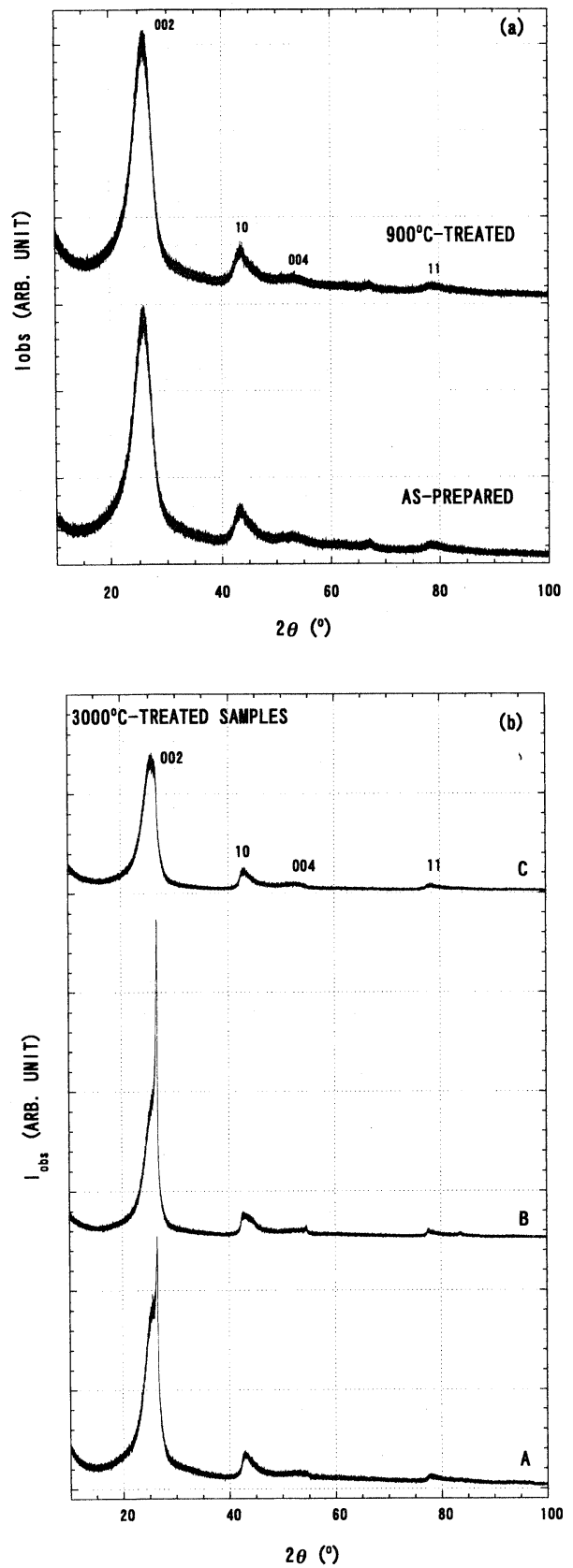

Fig.1 X-ray diffraction patterns of samples. (a) as-prepared and $900^{\circ} \mathrm{C}$-treated samples, (b) $3000^{\circ} \mathrm{C}$-treated samples $\mathrm{A}, \mathrm{B}$ and $\mathrm{C}$.

$0.243 \mathrm{~nm}, 3.4 \mathrm{~nm}$ で, $L_{a}$ は入射X線に対してコヒーレントな炭素 六方網面の平均寸法に相当する。

$3000^{\circ} \mathrm{C}$ 処理試料の場合, 試料AおよびBの場合, 002回折線は ブロードな回折線とその回折線のピークよりも高角側にピー クをもつ鋭い回折線からなっている。また, 試料Cにおいても 002回折線は微弱な鋭い回折線がブロードな回折線に重なっ た形になっている。一方, A, B, Cにおける002回折線の線幅
Table 3 Type of crystallite, average interlayer spacing $d_{002}$ determined from 002 line and average crystallite thickness $L_{c}$ along radial direction of MWCNT for asprepared, $900^{\circ} \mathrm{C}$-treated and $3000^{\circ} \mathrm{C}$-treated MWCNT samples (A, B and C).

\begin{tabular}{|c|c|c|c|}
\hline Sample & Crystallite & $d_{002}(\mathrm{~nm})$ & $L_{c}(\mathrm{~nm})$ \\
\hline As-prepared & Turbostratic & 0.3445 & 2.8 \\
\hline $900^{\circ} \mathrm{C}$-treated & Turbostratic & 0.3445 & 2.8 \\
\hline \multirow{2}{*}{$3000^{\circ} \mathrm{C}$-treated A A } & Turbostratic & 0.3538 & 3.5 \\
\cline { 2 - 4 } & Turbostratic & 0.3399 & 9.7 \\
\hline \multirow{2}{*}{$3000^{\circ} \mathrm{C}$-treated B B } & Turbostratic & 0.3494 & 3.9 \\
\cline { 2 - 4 } & Graphitic & 0.3370 & 26.9 \\
\hline \multirow{2}{*}{$3000^{\circ} \mathrm{C}$-treated C C } & Turbostratic & 0.3531 & 3.3 \\
\cline { 2 - 4 } & Turbostratic & 0.3398 & 9.4 \\
\hline
\end{tabular}

は, 総体的にas-prepared試料および $900^{\circ} \mathrm{C}$ 処理試料の線幅より 狭いが, 奇妙なことにブロードなピークのピーク位置は $3000^{\circ} \mathrm{C}$ 処理前よりも低角側にシフトしている。002回折線の 場合はブロードなピークと鋭いピークに分離することができ るが, 10回折線や11回折線の場合は回折強度が微弱なことか ら，それぞれを002回折線の鋭いピークに対応するピークとブ ロードなピークに対応するピークに分離することはできない。

得られた回折線に原子散乱因子およびローレンツ偏光因子 に対する補正を施した回折パターンを解析ソフトGRAMS/32 AI version 6によってピーク分離を行うことによって求めた $d_{0102}, L_{c}$ の值をTable 3 に示す。 $d_{002}$ の值や10, 11 回折線プロフ アイルを参照すると, 鋭い 002 線を示す領域の結晶性は低く, 試料B内の領域が黒鉛化度の低い黒鉛構造をとっているもの のAおよびC内のこの領域は乱層構造をとっている。 $L$ 值が 個々のMWCNTの直径と同程度あるいはそれ以上であること から,この領域は高温処理によって生じたMWCNT以外の領 域とすることができよう。

\section{1 .2 ホウ素ドープ試料}

Fig.2にホウ素ドープ試料の回折パターンを示す。

試料Aにおける鋭い002回折線のピーク強度はホウ素ドー プによってやや増加し, ピーク位置はやや高角側にシフトす る(Fig.2 (a))。また, ホウ素化合物による微弱なピークが星. 印の位置に測定される。よって試料A-B2には微量のホウ素 化合物, おそらく $\mathrm{B}_{4} \mathrm{C}$ 微粒子が生成し, MWCN中に混在してい ると考えられる。

試料Bにおいては，ホウ素ドープによって鋭い002回折線の 強度は増し, 明瞭な101回折線と微弱ではあるが112回折線が 出現する $(\boldsymbol{F i g . 2}$ (b))。これらの回折線は鋭い002回折線を示 す領域に関連させることができ, その領域は黒鉛構造をもつ 領域 ( $\mathrm{G}$ 領域) とすることができる。試料B-B1においては, 少 量ではあるが $\mathrm{B}_{4} \mathrm{C}$ 微粒子も生成していることがわかる。 $\mathrm{B}_{4} \mathrm{C}$ 微粒子の数は,さらなるホウ素ドープによる関連回折線のピ 一ク強度の増加から増加すると考えられる。しかし, B-B2に おける002回折線の鋭い回折線のブロードな回折線に対する 強度比はホウ素ドープ回数の増加によってむしろ減少してい 

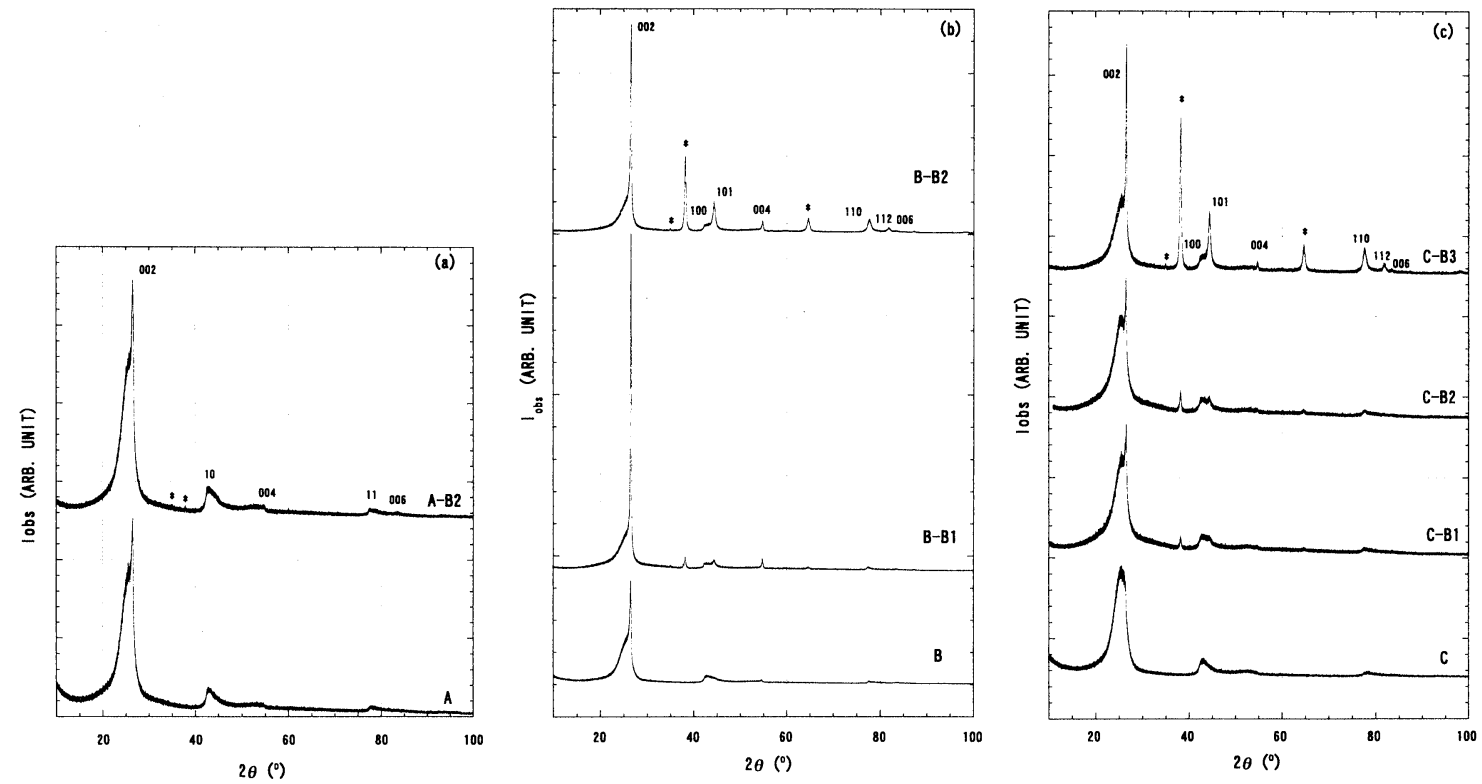

Fig.2 X-ray diffraction patterns of $3000^{\circ} \mathrm{C}$-treated and born-doped samples. (a) samples A and A-B2, (b) samples B, B-B 1 and B$\mathrm{B} 2$, and (c) samples C, C-B1, C-B2 and C-B3. The asterisk in the figure indicates the diffraction line due to other than carbon and graphite crystals.

Table 4 Type of crystallite, average interlayer spacing $d_{002}$ determined from 002 line and average crystallite thickness $L_{c}$ along radial direction.

\begin{tabular}{|c|c|c|r|}
\hline Sample & Crystallite & $d_{002}(\mathrm{~nm})$ & $L_{c}(\mathrm{~nm})$ \\
\hline \multirow{2}{*}{ A-B2 } & Turbostratic & 0.3491 & 3.5 \\
\cline { 2 - 4 } & Graphitic & 0.3364 & 18.6 \\
\hline \multirow{2}{*}{ B-B1 } & Turbostratic & 0.3471 & 4.1 \\
\cline { 2 - 4 } & Graphitic & 0.3356 & 44.4 \\
\hline \multirow{2}{*}{ B-B2 } & Turbostratic & 0.3471 & 4.1 \\
\cline { 2 - 4 } & Graphitic & 0.3356 & 36.0 \\
\hline \multirow{2}{*}{ C-B1 } & Turbostratic & 0.3494 & 3.4 \\
\cline { 2 - 4 } & Graphitic & 0.3365 & 21.9 \\
\hline \multirow{2}{*}{ C-B2 } & Turbostratic & 0.3503 & 3.4 \\
\cline { 2 - 4 } & Graphitic & 0.3365 & 31.4 \\
\hline \multirow{2}{*}{ C-B3 } & Turbostratic & 0.3491 & 3.4 \\
\cline { 2 - 4 } & Graphitic & 0.3356 & 44.7 \\
\hline
\end{tabular}

る。このことは, $\mathrm{G}$ 領域が平板状粒子であれば, 試料をX線回 折実験用試料ホルダーに充填したときに生ずる充填の選択的 配向によるとすることができる。

試料Cにおいては，ホウ素ドープの回数とともに002回折線 の鋭いピークの強度と $\mathrm{B}_{4} \mathrm{C}$ 微粒子に関連する回折線の強度が 増加していることがわかる (Fig.2 (c))。

Fig.20002回折線に原子散乱因子とローレンツ偏光因子に 対する補正を施し, 解析ソフトGRAMS/32 AI version 6を用い

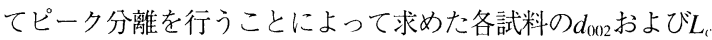
の值をTable 4に示す。また, $d_{002}$ 対 $x_{B}$ プロットをFig.3に示す。 Fig.3は, MWCNTが $3000^{\circ} \mathrm{C}$ 処理によって $d_{002}$ の大小によって 区別される2つの領域に分けられ，いずれにおいても $d_{002}$ が $x_{B}$ と ともに減少することを示す。 $d_{002}$ の小さな領域における $L_{c}$ の值

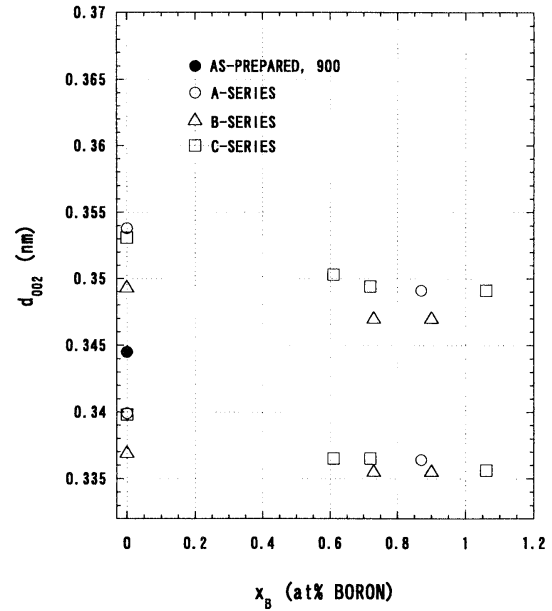

Fig.3 Average interlayer spacing $d_{(02)}$ plotted as a function of boron concentration $x_{B}$ for as-prepared, $900^{\circ} \mathrm{C}$-treated, $3000^{\circ} \mathrm{C}$-treated, boron-doped samples.

はMWCNTの直径よりも大きいから，この領域は結晶性の高 い薄片状G領域と考えられ，もう1つはMWCNTそのものとす ることができる。炭素および黒鉛へのホウ素ドープの効果 が, 結晶成長の促進とホウ素原子が炭素原子と置換すること

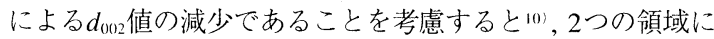
おける $x_{B}$ に対する $d_{002}$ の減少は, 出発試料 $\mathrm{A}, \mathrm{B}, \mathrm{C}$ 個性が反 映されてはいるものの, 薄板状 $\mathrm{G}$ 領域のみならずMWCNTに おいても少量の炭素原子がホウ素原子によって置換された ことを示す。 


\section{2 走査電子顕微鏡観察}

FESEMによる観察例をFig.4に示す。Fig.4 (a) はas-prepared 試料の钼察絬果走示し, Fig, 4 (b)，(c)，(d) はそ扎ぞれ $3000^{\circ} \mathrm{C}$ 処理試料。試料C-B1求よびC-B3に対する钼繁結果者小寸

Fig.4 (c) おおよび (d)では絡み合ったMWCNFの中にB⿺辶微小 結晶粒尗の介在が見ら扎る

セミインレンズ型FESEMによる観察結果をFig.5に小寸 Fig.5 (a) はas-prepared試料の形態観察結果走示L, Fig.5 (b). (c)，(d)はそ扎ぞれ $30000^{\circ} \mathrm{C}$ 処玾試料，ホウ素ドープ試料·A-B2 拉よびB-B1の形態観察絬果在小す。MWCNTの形態は $3000^{\circ} \mathrm{C}$ 処理，ホウ素ドープ処理によってほとんと变化しない ことがわかる。一方, Fig.5 (c) はホウ素ドープ処理によって
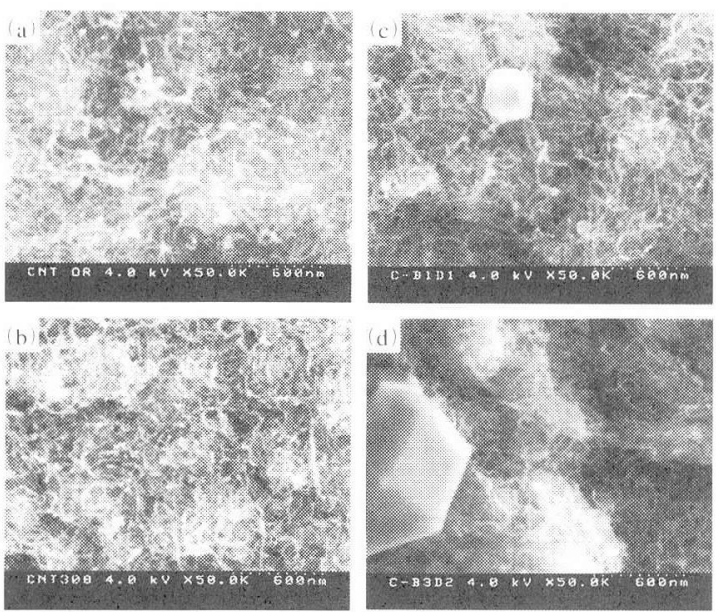

Fig.4 Examples of SEM micrographs for as-prepared, $3000^{\circ} \mathrm{C}$ treated and boron-doped samples. (a) as-prepared sample, (b) sample C. (c) sample C-B I and (d) sample C-B3.
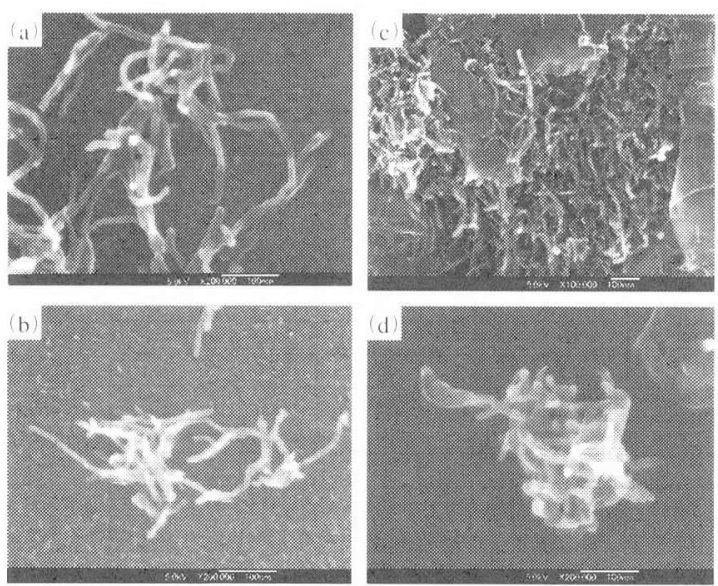

Fig.5 Examples of high resolution SEM micrographs for asprepared, $3000^{\circ} \mathrm{C}$-treated and boron-doped samples. (a) as-prepared sample, (b) sample B, (c) sample A-B2 and (d) sample B-B I. In each micrograph, the horizontal line for magnification indicates $100 \mathrm{~nm}$.
薄片状微結晶が生成したことを寺す。ただし, 薄片状微結晶 は、量的にはこの視野に見られるほど多く存在しないこと在 記しておく。

X線回折実験の結果と走查電子顕微鏡観祭結果から, 本報 のホウ素ドープ処理MWCNTは少量のホウ素原子が炭素原了 と置换したMWCNTと少量のホウ素原子が炭素原子と置換し

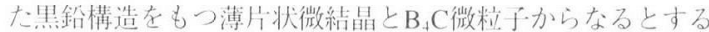
ことができる

\section{3 ラマンスペクトル}

\subsection{1 未ドープ試料}

As-prepared 武料抽よび $9000^{\circ} \mathrm{C}$ 処理試料のラマンスペクトル はほとんど变わらない。雨試料のラマンスペクトルをFig.6 (a)にホすすすずに2.2に执いて記したように, as-prepared 料および900C処理武料はレーザー光照射によってダメージ 老受けるので、レーザー光のパワーを通常測定に拈けるより も約1/100に落として测定したから、スペクトルは高雑音のス ベクトルとして得られた。測定されたラマンバントはは次ス ペクトルに拈けるDバンドとGバンド, 2次スペクトル(1次ス ベクトルの倍音または複合音)に拈ける2Dバンドと $\mathrm{D}+\mathrm{G}$ ハ ンドである。 Gバンドは黑鉛型積層に扮ける炭素原子のラマ ン活吽振動 $\left(\mathrm{E}_{2 \mathrm{2} 2}\right.$ モード)に斗来し, 乱層構造在もつ炭素に求 いても測定される。 Dバンドは試料結晶の不完全性に由来す る。単結晶黑鉛の1次スペクトルにはDバンドは出現しない。 2Dバンドも単結晶黑鎦に扔いてダブレットとして観測当れ るパンドで, 結晶化度の低下に徉いシングレットとして钼測 さ扎る。 $\mathrm{D}+\mathrm{G}$ バンドは試料結晶の不完全吽に曲来するパン ドであるので単結晶黑鉛においては観测されれい。したがっ て, D, 2D扰よ゙D+GバンドのGバンドに対する相刘強度は 結晶完全性を㛟討する上で重要な因了となっている。

$3000^{\circ} \mathrm{C}$ 処理試料 $\mathrm{A}, \mathrm{B}, \mathrm{C}$ のラマンスペクトルをFig.6 (b) (c)，(d)に亦す。 $3000^{\circ} \mathrm{C}$ 処理前に1より大きかったDバンド のGバンドに対する相対強度は $3000^{\circ} \mathrm{C}$ 処理によって著しく減 少し, 2Dバンドの相刘強度は増加し, D $+\mathrm{G}$ バンドの相対強度 は減少した。このことは炭素公俩網面の連絬性が熱処理によ って著しく改善されたこと在小す

\subsection{2 ホウ素ドープ試料}

ホウ素10wt％含有黑銿ブロック $\mathrm{GB} 110$ が $\mathrm{B}_{4} \mathrm{C}$ 結晶子老含古 ことはX線回折実験によってわかったが, そのラマンスペクト ルは $\mathrm{B}_{4} \mathrm{C}$ 結晶子の影響をまったく受けないこともラマンスヘ クトル測定によって確かめることができた。

ホウ素ドープ試料に対するラマンスペクトルの測定結果を Fig.6 (b)，(c)，(d)に示す。ホウ素ドープ試料では，D抄よむ゙

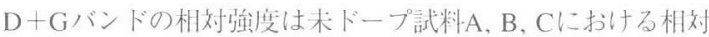
强度よりも吕く現机ている。特に, 武料A-B2, B-B2, C-B1, CB2においては、Dバンドの相対強度は、超える。このような 振る舞いはMWCNTの炭素原子と置換したホウ素原子と， $3000^{\circ} \mathrm{C}$ 処理あるいはホウ素ドープ処理中に生成したと考えら 

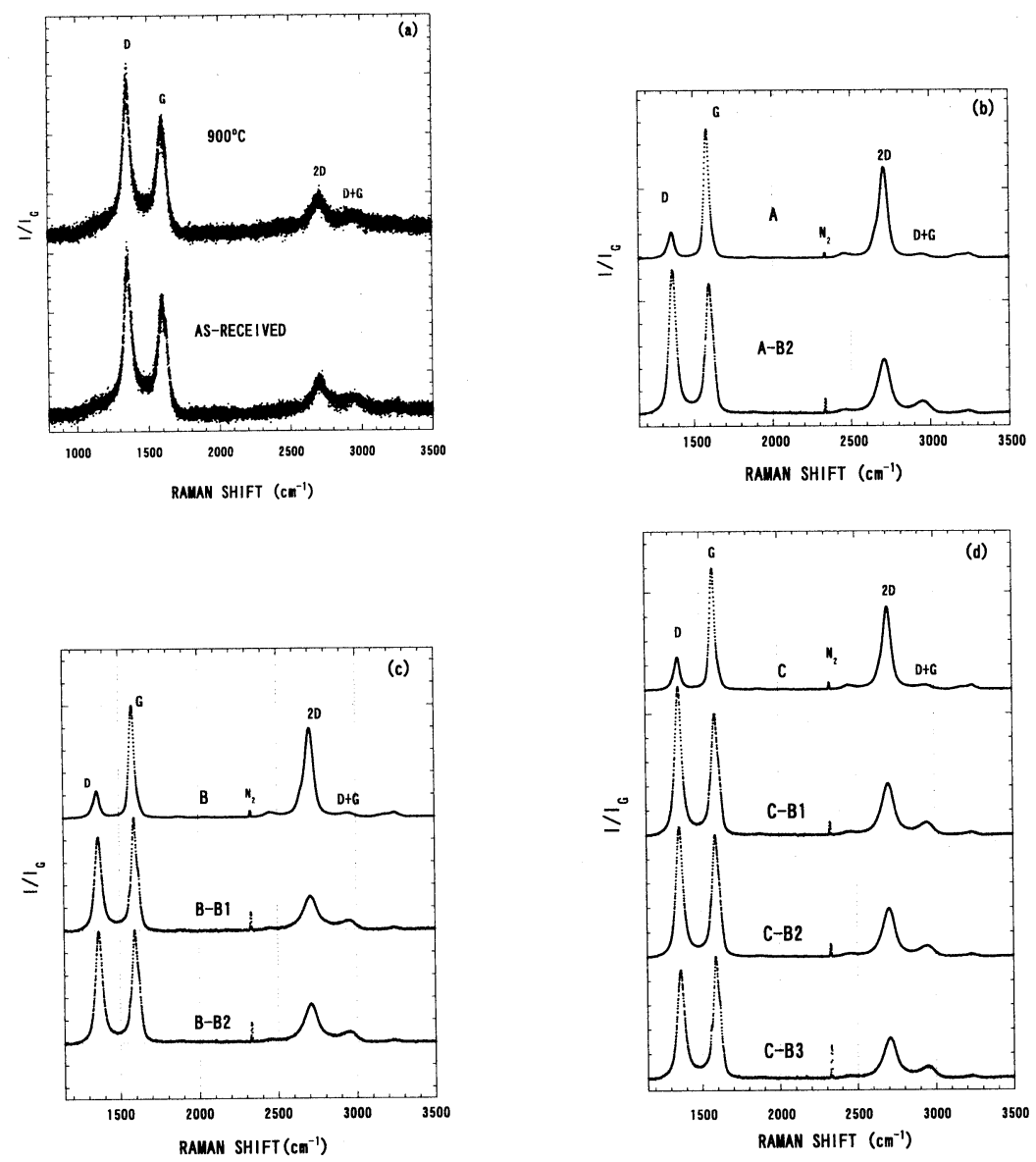

Fig.6 Raman spectra with relative intensity to $\mathrm{G}$ band for as-prepared, $900^{\circ} \mathrm{C}$-treated, $3000^{\circ} \mathrm{C}$-treated and boron-doped samples. (a) as-prepared and $900^{\circ} \mathrm{C}$-treated samples, (b) samples A and A-B2, (c) samples B and B-B1 and -B2, (d) samples C, C-B 1, C-B2 and C-B3.

Table 5 Raman frequency at peak position $v$, relative intensity to $\mathrm{G}$ band $\mathrm{I} / \mathrm{I}_{\mathrm{G}}$ and full width at half maximum intensity $\mathrm{W}_{1 / 2}$ for $3000^{\circ} \mathrm{C}$ treated MWCNT samples (A, B and C) and their boron doped samples. B after A-, B- and C- indicates boron doping and number 1 or 2 or 3 represents doping time in hr.

\begin{tabular}{|c|c|c|c|c|c|c|c|c|c|c|c|}
\hline \multirow[b]{2}{*}{ Sample } & \multicolumn{3}{|c|}{ D band } & \multicolumn{2}{|c|}{$\mathrm{G}$ band } & \multicolumn{3}{|c|}{$2 \mathrm{D}$ band } & \multicolumn{3}{|c|}{$\mathrm{D}+\mathrm{G}$ band } \\
\hline & $\begin{array}{c}v \\
\left(\mathrm{~cm}^{-1}\right)\end{array}$ & $\mathrm{I} / \mathrm{I}_{\mathrm{G}}$ & $\begin{array}{c}\mathrm{W}_{1 / 2} \\
\left(\mathrm{~cm}^{-1}\right)\end{array}$ & \begin{tabular}{|c|}
$v$ \\
$\left(\mathrm{~cm}^{-1}\right)$ \\
\end{tabular} & $\begin{array}{r}\mathrm{W}_{1 / 2} \\
\left(\mathrm{~cm}^{-1}\right)\end{array}$ & $\begin{array}{c}v \\
\left(\mathrm{~cm}^{-1}\right)\end{array}$ & $\mathrm{I} / \mathrm{I}_{\mathrm{G}}$ & $\begin{array}{c}\mathrm{W}_{1 / 2} \\
\left(\mathrm{~cm}^{-1}\right)\end{array}$ & \begin{tabular}{|c|c} 
\\
$\left(\mathrm{cm}^{-1}\right)$ \\
\end{tabular} & $\mathrm{I} / \mathrm{I}_{\mathrm{G}}$ & $\begin{array}{c}\mathrm{W}_{1 / 2} \\
\left(\mathrm{~cm}^{-1}\right)\end{array}$ \\
\hline As-prepared & 1355 & 1.38 & 73 & 1594 & 78 & 2700 & 0.270 & 120 & 2955 & 0.105 & 213 \\
\hline $900^{\circ} \mathrm{C}$ & 1356 & 1.39 & 74 & 1595 & 79 & 2701 & 0.273 & 119 & 2955 & 0.117 & 258 \\
\hline A & 1359 & 0.201 & 62 & 1583 & 38 & 2707 & 0.700 & 67 & 2950 & 0.025 & 78 \\
\hline $\mathrm{A}-\mathrm{B} 2$ & 1363 & 1.1 & 53 & 1596 & 58 & 2708 & 0.416 & 93 & 2950 & 0.092 & 94 \\
\hline B & 1358 & 0.237 & 45 & 1584 & 39 & 2707 & 0.789 & 66 & 2952 & 0.034 & 80 \\
\hline B-B & 1365 & 0.8 & 53 & 1594 & 43 & 2706 & 0.290 & 102 & 2951 & 0.078 & 93 \\
\hline B-B2 & 1365 & 0.989 & 52 & 1594 & 48 & 2708 & 0.337 & 99 & 2952 & 0.087 & 96 \\
\hline C & 1357 & 0.267 & 48 & 1582 & 37 & 2705 & 0.678 & 65 & 2949 & 0.036 & 79 \\
\hline $\mathrm{C}-\mathrm{B} 1$ & 1360 & 1.225 & 55 & 1590 & 55 & 2704 & 0.418 & 94 & 2946 & 0.101 & 92 \\
\hline C-B2 & 1360 & 1.069 & 53 & 1590 & 55 & 2703 & 0.394 & 93 & 2943 & 0.087 & 91 \\
\hline C-B3 & 1363 & 0.890 & 56 & 1590 & 48 & 2706 & 0.326 & 100 & 2948 & 0.088 & 99 \\
\hline
\end{tabular}

れる黒鉛構造をもつ薄片状微結晶に扔いて炭素原子と置換し

たホウ素原子によると考えられる。後者の前者に対する量的

割合は低いとすると, 後者によるD抢よ゙ $\mathrm{D}+\mathrm{G}$ バンドへの寄
与は量的には小さいものと考えられる。

解析ソフトGRAMS/32 AI version 6によるFig.6のスペクトル の解析結果をTable 5に表示する。得られた各バンドのラマン 

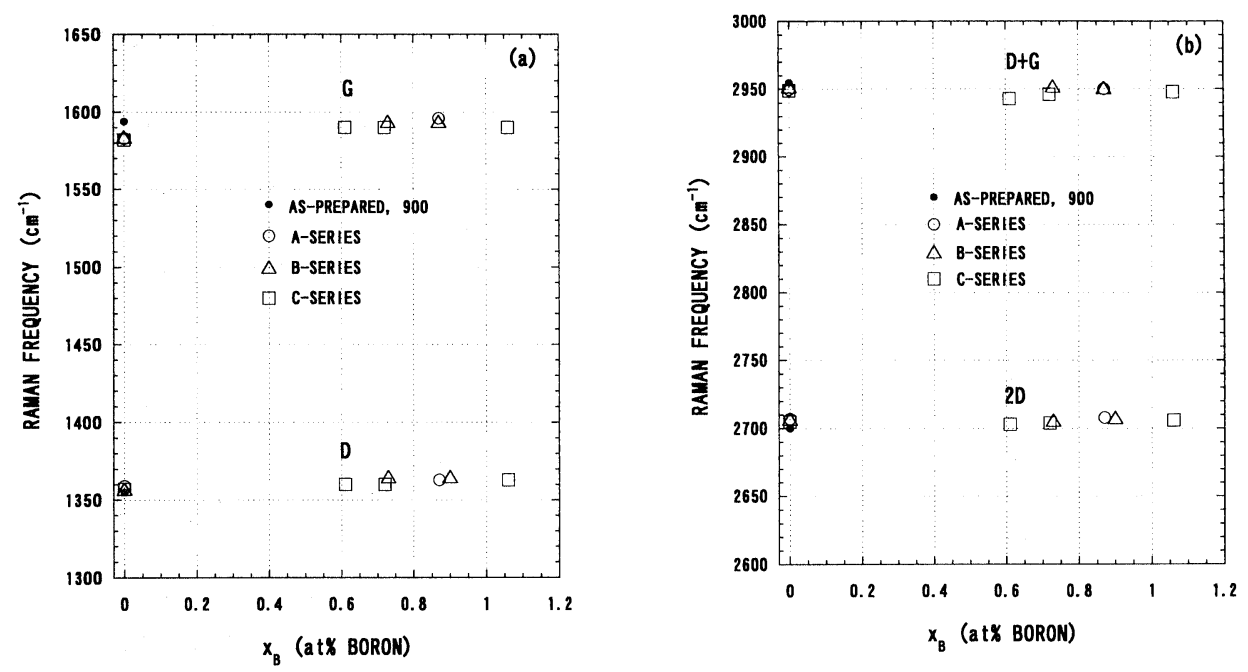

Fig.7 Raman frequency at peak position plotted as a function of boron concentration $x_{B}$. (a) D and G bands, and (b) $2 \mathrm{D}$ and $\mathrm{D}+\mathrm{G}$ bands.
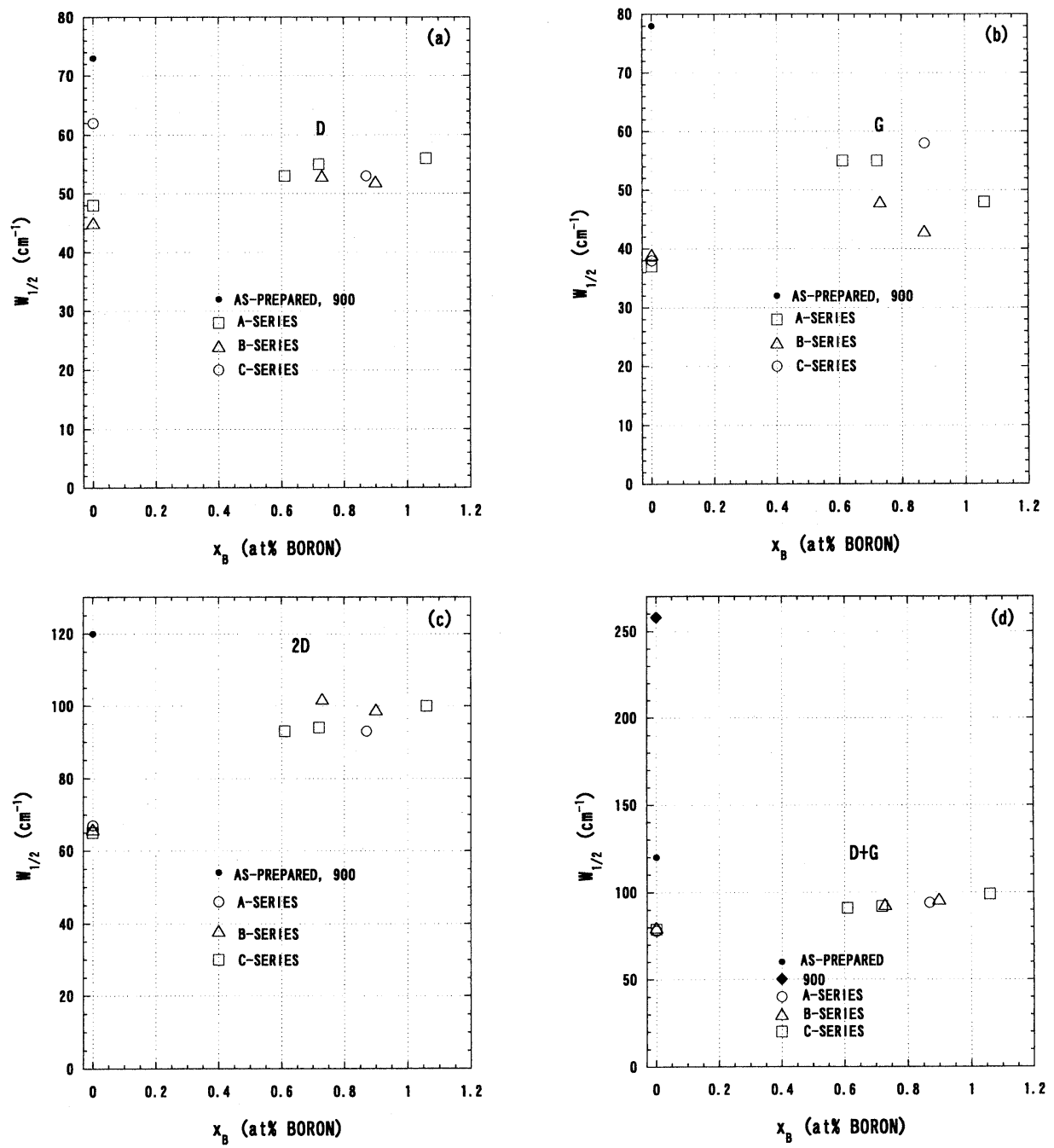

Fig.8 Full width at half maximum intensity $\mathrm{W}_{1 / 2}$ plotted as a function of $x_{B}$. (a) D band, (b) G band, (c) $2 \mathrm{D}$ band and (d) D $+\mathrm{G}$ band. 

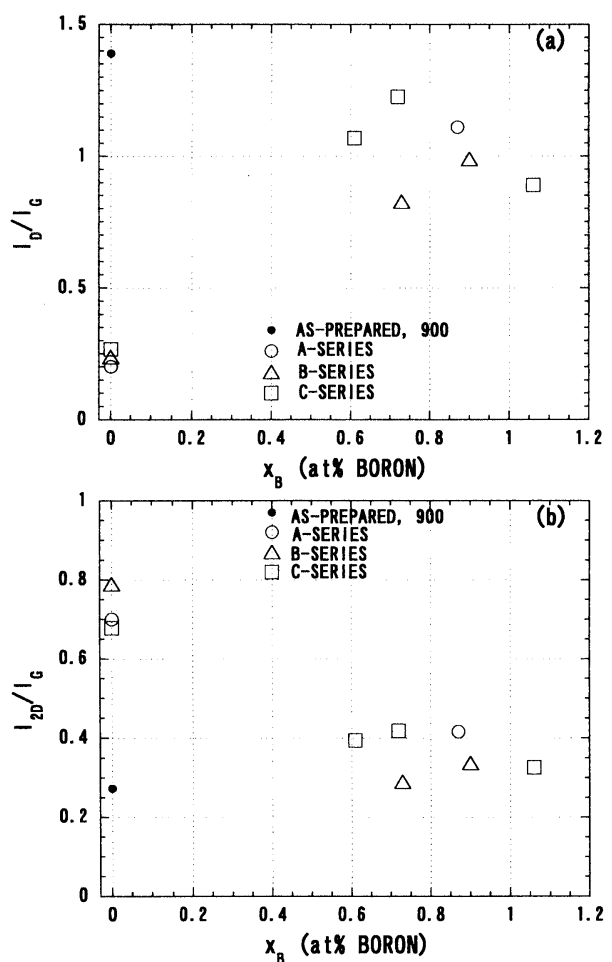

$x_{B}$ (at\% BORON)

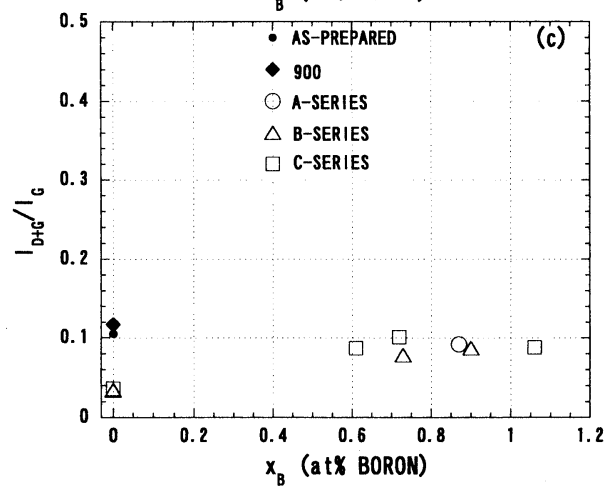

Fig.9 Relative intensity to $\mathrm{G}$ band plotted as a function of $x_{B}$. (a) D band, (b) 2D band and (c) D + G band.

振動数, 半值幅ならびに相対強度をFig.7 Fig.9にホウ素濃度 $x_{B}$ に対してプロットする。プロットの結果は次のとおりである。

(1) $\mathrm{D}, \mathrm{G}, 2 \mathrm{D}$ 抢よび $\mathrm{D}+\mathrm{G}$ バンドのラマン振動数は $x_{B}$ とともに 緩やかに増加する。

（2） Dバンドの半值幅には $3000^{\circ} \mathrm{C}$ 処理試料におけるばらつき があるにもかかわらず, 各ドープ試料は半值幅が $x_{B}$ とと もに増すほぼ統一した挙動を示す。

（3）Gバンドの半值幅はホウ素ドープによって増すが，その $x_{B}$ に対する変化は出発試料によってまちまちである。

（4） $2 \mathrm{D}$ バンドの半值幅については，各試料は $x_{B}$ とともに増す ほほ統一した挙動を示す。

（5） $\mathrm{D}+\mathrm{G}$ バンドの半值幅は $x_{B}$ とともに増す 1 本の直線上にのる。 （6） $\mathrm{D}$ バンドの相対強度はホウ素ドープによって著しく増す
が、ドープ試料における $x_{B} に$ に対する変化には規則性が見 られない。

（7） $2 \mathrm{D}$ バンドの相対強度はホウ素ドープによって著しく減 少するが，ドープ試料における $x_{B} に$ に対する变化には規則 性が見られない。

（8） $\mathrm{D}+\mathrm{G}$ バンドの相対強度はホウ素ドープによって増すが， ドープ試料に拀ける相対強度は $x_{B} に$ に対してほとんど変化 しない。

ところで, 易黑鉛化性炭素として知られているべンゼン系気 相成長炭素瀻維においては, DバンドとGバンドで半值幅は熱 処理温度とともに減少することが知られているい。またた片 桐はGバンドの半值幅は黒鉛化度, すなわち, ローカルな黒鉛 構造の完全性を反映するパラメーターであることを提案して いる(2)。ホウ素ドープは1種の逆黒鉛化であるが，これらの関 係との対応はDバンドにおける半值幅のみである。ホウ素ド ープ試料がラマン散乱に対して2相系になっていることがそ の要因の1つとなっているとも考えられる。

\section{4 電気抵抗率}

Fig.10に液体窒素温度 $(77 \mathrm{~K})$ および室温 $(300 \mathrm{~K})$ における 試料の電気抵抗率 $\rho$ をホウ素濃度 $x_{B}$ に対してプロットした。 $\rho$ はホウ素ドープによって著しく減少し, 極小值を経て増加す る。減少の傾向はホウ素ドープグラフォイルの場合と同様で ある131。 $\rho$ の主要な变化が置換ホウ素をもつMWCNTによると すると，その変化は次のように説明することができる。すなわ ち, MWCNTのエネルギーバンドがquasi-two-dimensional graphite (QTDG)のバンドモデルによって表すことができ(4), バンド形状がホウ素ドープによって変わらないとすると (ridged band), フェルミ準位はホウ素ドープによって価電子バ ンドの頂上から押し下げられ，正孔による電気伝導が行われ る。この場合, 電気抵抗率は次のように表すことができる。

$$
\rho=1 / n_{h} e \mu_{h}
$$

ここで, $n_{h}$ は正孔濃度, $e$ は電気素量, $\mu_{h}$ は正孔の移動度であ る。(1) 式に掠いて, $n_{h}$ はMWCNTの層面内の炭素原子と置換 したホウ素原子の濃度に対応しホウ素濃度の増加とともに増 加する。 $\mu_{h}$ は正孔の有効質量を $m_{h}$, 緩和時間を $\tau_{h}$ とすると,

$$
\mu_{h}=\frac{e \tau_{h}}{m_{h}}
$$

と表すことができる。元 は置換したホウ素原子の濃度が増加 すると減少するから， $\mu_{4}$ はホウ素濃度の増加とともに減少する ことになる。また, 試料中に混在する $\mathrm{B}_{4} \mathrm{C}$ 微結晶粒子は絶縁体 であるからこれもて を下げる要因となっている。よって, $\rho$ は ホウ素ドープによる $n_{h}$ の増加率が, $\mu_{h}$ の隇少率に勝れば減少 し，逆であれば増加することになる。よって，試料C-B3におけ る $\rho$ の増加はC-B3において生成した $\mathrm{B}_{4} \mathrm{C}$ 微結晶粒子の量の増 加による $\mu_{h}$ の減少率が $n_{h}$ の増加率に勝ったからと説明できる。

Fig.11に電気抵抗率比 $\rho_{300 K} / \rho_{77 K}$ を $x_{B}$ に対してプロットした。 


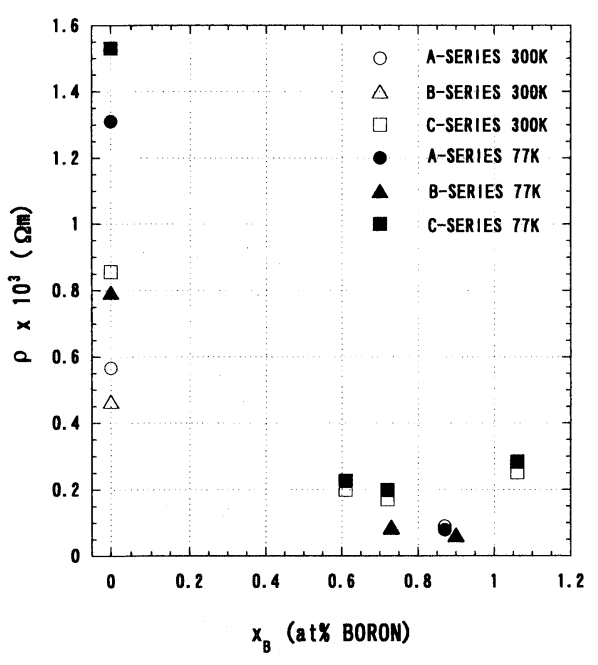

Fig.10 Electrical resistivities measured at 77 and $300 \mathrm{~K}$ plotted as a function of $x_{B}$.

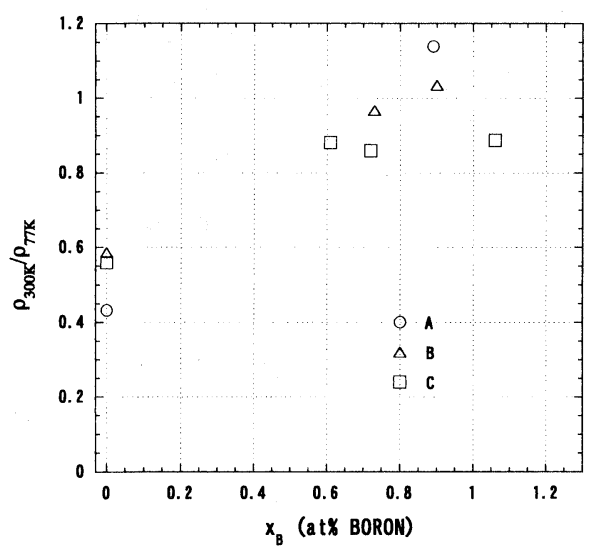

Fig.11 Resistivity ratio $\rho_{300 \mathrm{~K}} / \rho_{77 \mathrm{~K}}$ for samples plotted as a function of $x_{B}$.

MWCNTの $\rho$ の温度変化はホウ素ドープすることによって弱 められる。しかし, 変化の過程は2種類に分けられる。出発試 料A, Bの場合, 電気抵抗率の温度変化はより金属的になるが, 出発試料 $\mathrm{C}$ 場合は $\rho_{300 \mathrm{~K}} / \rho_{77 \mathrm{~K}}$ は $x_{B}$ に対してほとんど変化しな い。これらの変化の差異に対する由来は本実験からは定かに ならない。

\section{5 磁化率}

MWCNTの磁化率は反磁性でその異方性は非常に大きい。 MWCNTの軸に沿っての磁化率は黒鉛の層面に沿っての磁化 率と同程度であるのに対し, 垂直な方向では, 軸に沿っての磁 化率よりもはるかに大きく, QTDGのバンドモデルによって 説明することができる14)。

MWCNTの軸に平行に磁場を加えたときの磁化率はQTDG の炭素層面に平行に磁場を加えたときの磁化率に一致し，そ
の值は閉殼電子のラーモア反磁性磁化率

$$
\chi_{a}=-0.5 \times 10^{-6} \mathrm{emu} \cdot \mathrm{g} \cdots 1
$$

に等しい。MWCNTの最も高い反磁性磁化率はその軸に垂直 に磁場を加えたときに得られる。これを东で表し，炭素六方 網面に垂直に磁場を加えたときの磁化率をれるすると

$$
\chi_{\perp}=\left(\chi_{3}+\chi_{a}\right) / 2
$$

の関係がある。磁化率の差 $\chi_{3}$ - $\chi_{4}$ は空の価電子帯と伝導帯の 接触点付近に位置するフェルミ準位 $E_{F}$ と温度に敏感であり, MWCNTが試料中で絡み合っていることによる方向平均化に より

$$
\chi_{3}-\chi_{a}=3<\chi-\chi_{a}>
$$

となる。記号く>は方向平均化を表す。QTDGバンドモデル によると, $\chi_{3}$ 一暂は次のようになる14)。

$$
\chi_{3}-\chi_{a}=-\frac{5.45 \times 10^{-3} \gamma_{0}^{2}}{(T+\delta)(2+\exp [\eta]+\exp [-\eta])} \mathrm{emu} \cdot \mathrm{g}^{-1}
$$

ここで, $\gamma_{0} \approx 3 \mathrm{eV}$ は2次元バンドパラメーターであり,Tは格子 温度, $\delta$ は格子欠陷によるキャリアーの非熱的散乱に対して取 り入れたパラメーター, $\eta$ は

$$
\eta=\frac{E_{F}}{k_{B}(T+\delta)}
$$

と定義され,電荷の中性条件

$$
F_{1}(\eta)-F_{1}(-\eta)=\frac{\eta_{0}^{2}}{2}
$$

によって決められる。 $k_{B}$ はボルツマン定数である。ここで $F_{1}(\eta)$ は1次フェルミ積分を表し,

$$
\eta_{0}=\frac{T_{0}}{T+\delta}
$$

であり, $T_{0}$ は縮退キャリアー系のフエルミエネルギーを $E_{F 0}$ と するとこれと $E_{F 0}=k_{B} T_{0}$ の関係にある。

MWCNTの炭素原子がホウ素原子によって置換され, フェ ルミ準位が大きく押し下げられると, 接触点付近のバンド構 造の寄与はなくなり, (3) 式は, 一定温度において $\chi_{3}-\chi_{a}$ が置 換したホウ素濃度 $x_{B}$ に対して著しく減少することを示す。

Fig.12は試料B, B-B1, -B2の5Kおよび300Kにおける反磁性 磁化率の $x_{B}$ 依存を示す。測定されたそれぞれの磁化率は極め て等方的で, 加えた磁場の方向によらない。この等方性は上 に記した個々のMWCNT同士の絡み合いに基づく方向平均化 による。試料Bの反磁性磁化率は大きく, ホウ素ドープによっ て著しく減少する。試料Bの磁化率の3倍がその全磁化率に対 応し, その值は文献14の結果に近く, 磁化率の温度变化の方向 も妥当なものであることがわかる。この大きな反磁性磁化率 はホウ素ドープによって減少し, 単結晶黑鉛の層面に平行に 磁場を加えたときの磁化率の值と同程度になり, 置換したホ ウ素原子の濃度にほとんど依存しなくなる。なお, 各試料に 対して測定した結果にはキュリー常磁性成分が含まれてい る。ホウ素ドープ試料B-B1, B-B2において, 反磁性磁化率が 低温で小さくなるのはこの事情の現れである。 


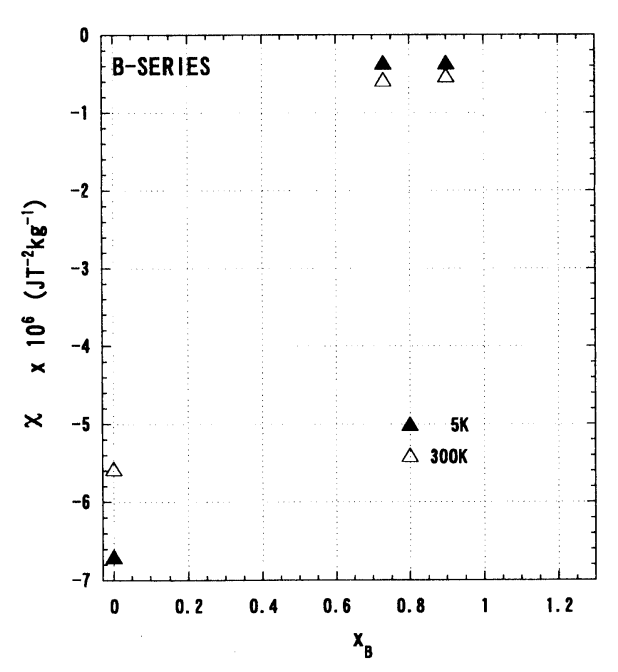

Fig.12 Magnetic susceptibilities measured at 5 and $300 \mathrm{~K}$ plotted as function of $x_{B}$ for samples B, B-B1 and B-B2.

\section{4. おわりに}

MWCNTの加圧成形体にホウ素をドープした。X線回折実 験とラマンスペクトルの測定から, ホウ素原子が, MWCNTの 炭素原子と置換したことが示された。液体窒素温度および室 温に打ける電気抵抗率のホウ素濃度 $x_{B}$ に対するプロットなら びに室温および液体窒素温度における抵抗率の比の $x_{B}$ プロッ トはホウ素原子の炭素原子との置換を示し, 磁化率の測定も この置換を裏付ける結果を示した。

\section{謝 辞}

本研究の一部は, 新エネルギー産業技術開発機構新規産業 創造型提案公募事業 (99E代10-009-3) の援助によるもので す。ここに謝意を表します。また, 走査電子顕微鏡観察には 武蔵工業大学工学部機器分析室 吉田 明助教授, 日本電子ハイ テク(株) 服部 隆氏, 矢島恵介氏にご協力いただきました。記し て感謝いたします。

\section{文 献}

1) S. Iijima, Nature 354 (1991) 56-58.

2) M. S. Dresselhaus, G. Dresselhaus and O. C. Eklund, Science of Fullerenes and Carbon Nanotubes (1996) Academic Press.

3) Y. Hishiyama, H. Irumano, Y. Kaburagi and Y. Soneda, Phys. Rev. 63 (2001) 245406.

4) Z. Weng-Sieh, K. Cherrey, N. G. Chopra, X. Blase, Y. Miyamoto, A. Rubio, M. L. Cohen, S. G. Louie, A. Zettl and R. Gronsky, Phy. Rev. B 51 (1995) 11229-11232.

5) P. Redlich, J. Loeffler, P. M. Ajayan, J. Bill, F. Aldinger, M. Ruhle, Chem. Phy. Let. 260 (1996) 465-470.

6) B. C. Satishkumar, A. Govindaraj, K. R. Harikumar, J. -P. Zhang, A. K. Cheetham and C. N. R. Rao, Chem. Phy. Let. 300 (1999) 473-477.

7) W. Han, Y. Bando, K. Kurashima and T. Sato, Chem. Phy. Let. 299 (1999) 368-373.

8) D. Golberg, Y. Bando, W. Han, K. Kurashima and T. Sato, Chem. Phy. Let. 308 (1999) 337-342.

9) S. Bandow, J. Appl. Phys. 80 (1996) 1020-1027.

10) Y. Hishiyama and M. Inagaki, Carbon 39 (2001) 137-158.

11) T. C. Chieu, M. S. Dresselhaus and M. Endo, Phys.Rev. 26 (1982) 4867-5877.

12) G. Katagiri, TANSO 1996 [No.175] 304-313 [in Japanese].

13) Y. Hishiyama, M. Matsutani, M. Suzuki, Y. Kaburagi and K. Sugihara, J. Mater. Res. 17 (2002) 75-82.

14) A. S. Kotosonov, JETP Lett. 70 (1999) 476-480. 